\title{
Alternative Measures of the Monetary Base
}

\author{
ALBERT E. BURGER
}

B monetary base an important variable in economic analysis, it has published monetary base data since August 1968 and has published numerous articles explaining the derivation of the monetary base and its uses in monetary analysis. ${ }^{1}$ Several months ago, the Board of Governors of the Federal Reserve System (BOG) be gan publishing monetary base data in their $\mathrm{H} .3$ and H.9 Statistical Releases and in the Federal Reserve Bulletin. Beginning on March 16, 1979, they published two monetary base series: a level series which did not incorporate the effects of reserve requirement changes and a growth rate series which incorporated such effects. Since the St. Lotlis series is adjusted for these effects, this Bank designated it the "Adjusted Monetary Base ${ }^{\text {t” }}$ to facilitate a clearer public differentiation between the alternative monetary base levels then being published. On June 15, 1979, the BOG began publishing the adjusted monetary base from which their previously published growth rate series had been derived.

There are several important differences among the various monetary base series now being published.

This Bank publishes monetary base data in its weekly publication, "U.S. Financial Data," and its monthly publication, "Monetary Trends." See also Leonall C. Andersen and Jerry L. Jordan, "The Monetary Base - Explanation and Analytical Use," this Review (August 1968), pp. 7-11, Albert E. Burger, Lionel Kalish III, and Christopher $\mathrm{T}$. Babb, "Money Stock Control and Its Implications for Monetary Policy, this Review (October 1971) pp. 6-22, Albert E. Burger, "Explanation of the Growth of the Money Stock: 1974-Early 1975," this Review (September 1975), pp. 5-10; Albert E. Burger, "The Relationship Between Monetary Base and Money: How
This article explains the key distinctions between the series in order to clarify the public's understanding of these differences.

\section{Computation of the Unadiusted Monedary Base: Similarites and Differences}

The St. Louis unadjusted base and the unadjusted monetary base initially published by the BOG have much in common. The basic components of both are (1) member bank deposits at Federal Reserve Banks and (2) currency in circulation, which consists of currency held by the nonbank public and vault cash in commercial banks. Also, as shown in Table I, the largest "source" of the unadjusted monetary base is Federal Reserve holdings of Government securities, which accounts for about 80 percent of the total.

Two minor ways in which computation of the St. Louis and the BOG unadjusted monetary base differ are in the methods of (1) treatment of member bank vault cash and (2) seasonal adjustment of data. They differ primarily in the degree of emphasis placed on the "sources" relative to the "uses" of the monetary

Close?" this Review (October 1975), pp. 3m; Leonall C. Andersen, "Selection of a Monetary Aggregate for Economic Stabilization," this Review (October 1975), pp. 9-15; Anatol B. Balbach and Albert E. Burger, "Derivation of the Monetary Base," this Review (November 1976), pp. 2-8; Albert E. Burger and Robert $H$. Rasche, "Revision of the Monetary Base," this Review (July 1977), pp. 13-23; and Leonall C. Andersen and Denis S. Karnosky, "Some Considerations in the Use of the Monetary Aggregates for the Implementation of Monetary Policy," this Review (September 1977), pp. 2-7. 


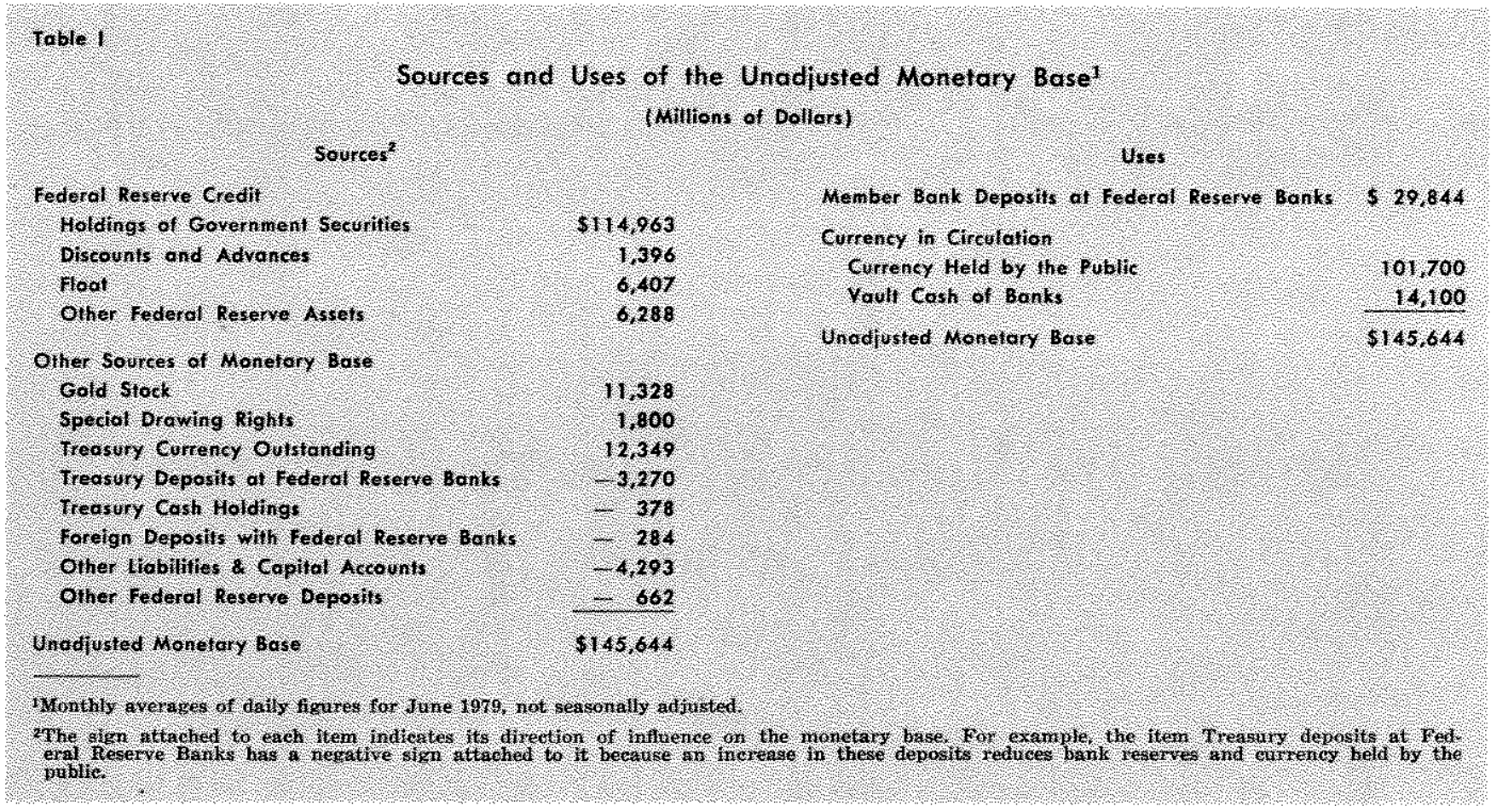

base (Table I). In general, these differences result in only small divergences between the growth rates of the two unadjusted monetary base series, as shown in Table II.

Vault Cash - The BOG unadjusted monetary base series includes the vault cash that member banks can use to meet their reserve requirements in the current week. Under the present system of lagged reserve accounting, this consists of vault cash held by member banks two weeks earlier (the member bank vault cash component of member bank reserves as reported in the Federal Reserve Bulletin). Since the St. Louis unadjusted monetary base is computed from a balance sheet identity (the sources of the base equal its uses), the current week's member bank vault cash appears in this series.

Seasonal Adjustment - The monetary base is "used" by commercial banks as member bank reserves and vault cash held by nonmember banks, and is also "tused" by the nonbank public as currency. These items represent the demand for the base. The Board of Governors seasonally adjusts each of these three use components of the base separately, then totals them to obtain its unadjusted monetary base. In contrast, the Federal Reserve Bank of St. Louis focuses on the "sources" of the monetary base, which reflect the factors that change the total amount of base supplied to the public and banks. Consequently, the source components of the base are first totalled (with appropriate sign), then this total is seasonally adjusted.

\section{The Rationale for Adjusting the Monetary Base for Changes in Reserve Requirements}

The monetary base has three main characteristics that make it useful in monetary analysis. First, it comprises the set of assets that constrain the amount of money supplied to the public. Second, it can be measured and controlled on a short-term basis by the Federal Reserve. Finally, it can be used as a summary measure of the net effect of Federal Reserve actions on the money stock. ${ }^{2}$

The monetary base incorporates the effects of two of the three major direct Federal Reserve actions that influence the money stock: open market operations (changes in Federal Reserve holdings of Government

"In the Report of the Advisory Committee on Monetary Statistics, "Improving the Monetary Aggregates," Board of Governors of the Federal Reserve System (June 1976), p. 8, the Advisony Committee on Monetary Statistics acknowledged the importance of the monetary base, noting that "it is the total among those considered here that can probably be most accurately measured and most precisely controlled by the Fed [and] ... this total does have the great advantage of being less subject to influence by financial innovations than are broader totals. Hence, we recommend that the Fed regularly publish figures on the base . . " 
Table II

Growth Rates of the St. Louis and Board of Governors Unadiusted Monetary Base Series: Selected Periods of Reserve Requirement Changes

\begin{tabular}{|c|c|c|c|}
\hline Period & $\begin{array}{l}\text { st, lowis } \\
\text { Unoduried } \\
\text { Banongory } \\
\text { Base Series }\end{array}$ & $\begin{array}{l}\text { Boord of } \\
\text { Governors } \\
\text { Unodjusted } \\
\text { Monetryy, } \\
\text { Bose Series }\end{array}$ & Difference \\
\hline $11 / 624,63$ & $17 \%$ & $1,6 \%$ & $0.1 \%$ \\
\hline $1 / 6311 \% 6$ & 54 & 5.4 & 0.0 \\
\hline $11 / 60.17 / 68$ & 5.4 & 6.7 & 0.0 \\
\hline $11 / 6611 / 67$ & 38 & 12 & +04 \\
\hline $11 / 67,11 / 67$ & 72 & 10 & 02 \\
\hline $1 / 167468$ & 90 & 87 & 0.3 \\
\hline $1168,1 / 69$ & 7.1 & 70 & 0.1 \\
\hline $116911 / 69$ & 60 & 6.2 & 0.2 \\
\hline $11 / 69.111 / 69$ & 1,5 & 2.8 & 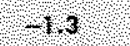 \\
\hline $111 / 69,14 / 69$ & 7.6 & 6.7 & 0.9 \\
\hline 1176911179 & 5.6 & $5 \%$ & 0.3 \\
\hline $111 / 70 / 1 / 73$ & 6.4 & 6.3 & 0.1 \\
\hline $1 / 7,14 / 73$ & 980 & 10.1 & -0.3 \\
\hline $14 / 73 \sqrt{77}$ & 6.3 & 62 & 0,1 \\
\hline $1 / 77,11 / 78$ & 8,8 & 89 & -0.1 \\
\hline $111778,1 / 79$ & 12,2 & 12.0 & 0.2 \\
\hline
\end{tabular}

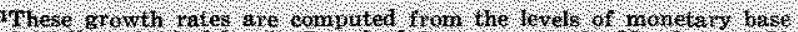

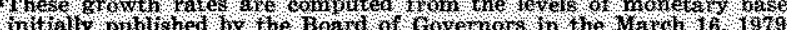
statistical Release of 3

securities) and Federal Reserve Bank loans to member banks. However, it excludes the effects on the monetary aggregates of the third major direct policy action, changes in legal reserve requirement ratios. If the monetary base is to be used as a measure that summarizes the effects of all Federal Reserve actions on the monetary aggregates, the effects of reserve requirement changes must also be included in the computation of the base.

If legal reserve requirement ratios were never changed and were uniform for all banks and all sizes of deposits, growth rates of both an adjusted and an unadjusted monetary base would be virtually the same. For example, there were no changes in legal reserve requirement ratios that noticeably affected required reserves from $\mathrm{I} / 63$ to $\mathrm{II} / 66$ and from $\mathrm{I} / 77$ to III/78. During these periods, the growth rates of all of the monetary base series, both adjusted and unadjusted, were approximately the same (Tables II and III).

However, whenever legal reserve requirement ratios are changed, the growth rates of a monetary base that

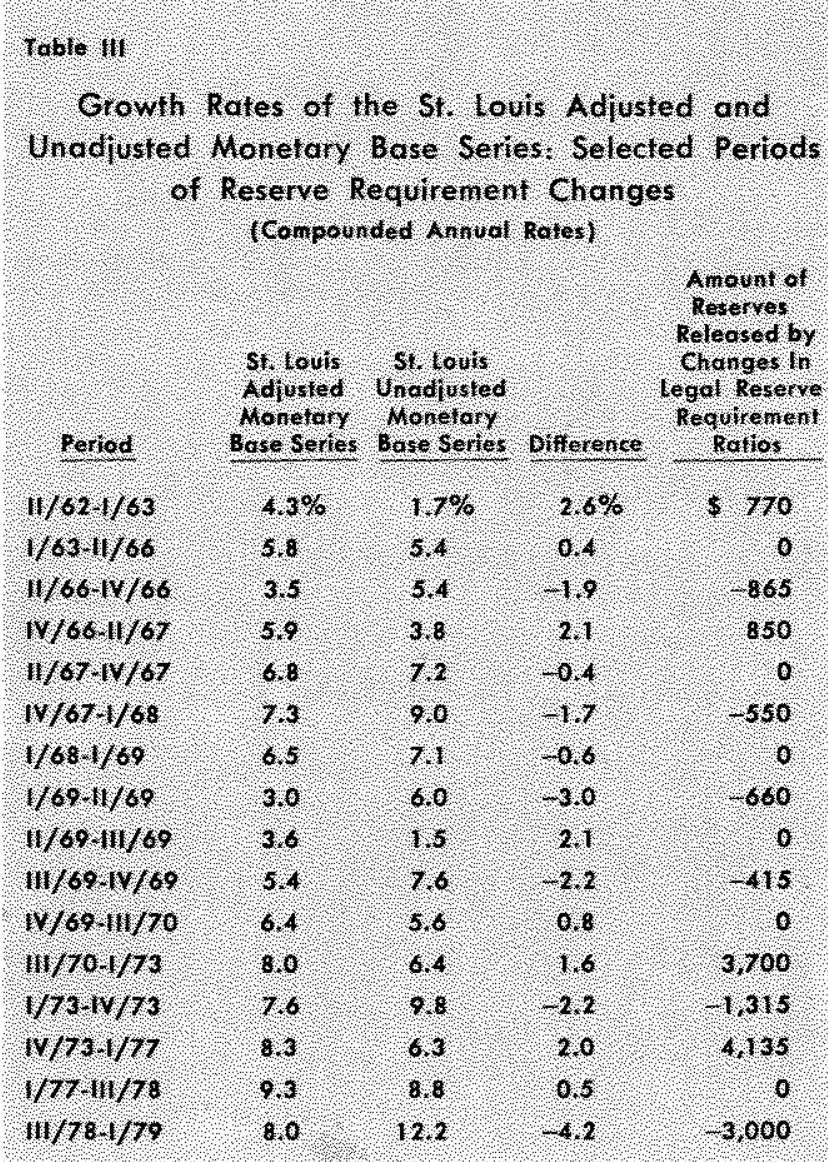

incorporates these effects and one that does not incorporate these effects usually diverge markedly. This is what happened, for example, at the end of 1978. During the first ten months of that year, the growth rate of the "base" was about 10 percent regardless of the base measure used. However, from October 1978 to February 1979 , an adjusted series indicates a deceleration in base growth to a 6.3 percent rate. In sharp contrast, a growth rate calculated using the levels of an unadjusted series, shows an acceleration in base growth to a 12.7 percent rate. This difference occurred in the November-December period when a change in reserve requirement ratios on time deposits (Table IV) increased member bank required reserves by about $\$ 3$ billion. A monetary base that incorporates the effect of higher reserve requirements indicates that the base grew at a 6.6 percent rate during this period. A monetary base that does not include such an adjustment indicates a 21.8 percent rate of growth.

This is not an isolated instance of the importance of incorporating the impact of changes in reserve requirements into a monetary base measure. Between mid-1960 and early 1977, the Board of Governors made 
Toble IV

Effeclive Dale

September 1,1960

Nowember 24,1960

December 1,1960

Oetober 25,1062

Novenber 1,1962

$1614,14,1966$

. $501,21,1966$

- September 8,1966

September 15,1966

March 2, 1967

* March 16,1967

Jonuory 11,1969

Jonuany 18,1968

Apil 17,1969

October 16,1969

Oclober 1,1970

\section{Changes in legal Reserve Requirement Ratios}

\section{Change}

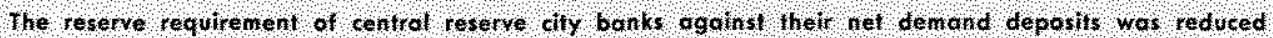

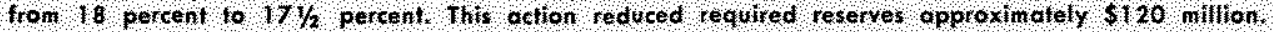

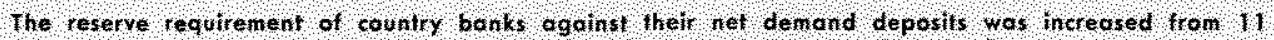

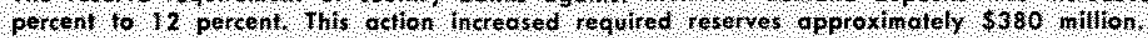

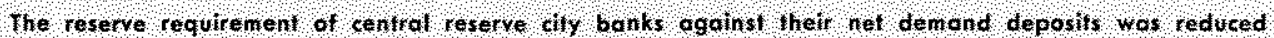

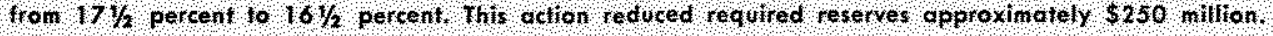

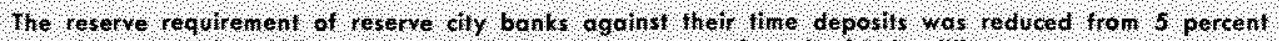
104 percent 1 his odion redued tequired reserves oppoxindel $\$ 410$ milon

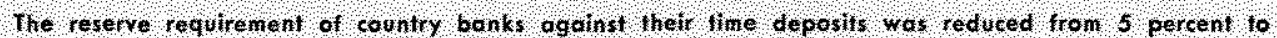

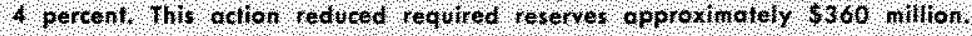

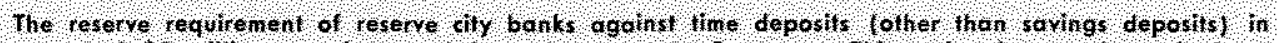

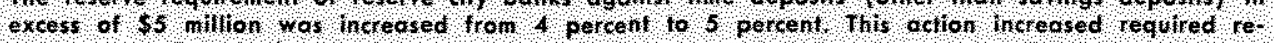
semes opproxhately $\$ 350$ millon.

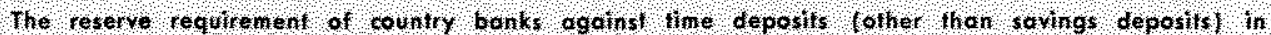

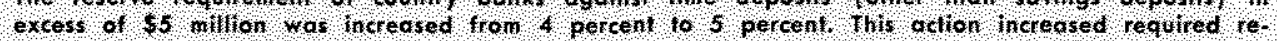
serres opproximolely $\$ 70$ nillons

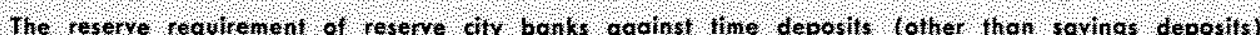

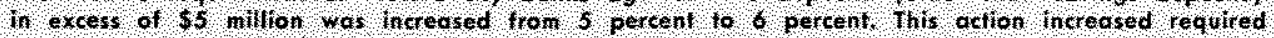
reserves opprox indely $\$ 370$ nillon,

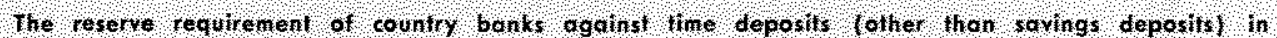

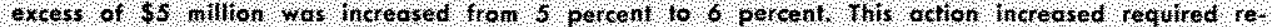
serves approximotely $\$ 75$ milion.

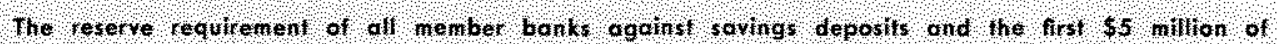

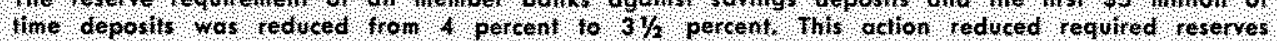
opproxinolely $\$ 425$ milian

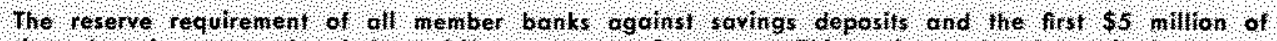

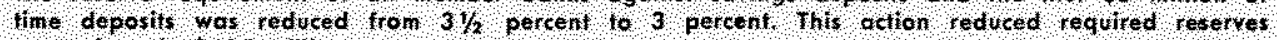
opproximaloly $\$ 425$ nillon

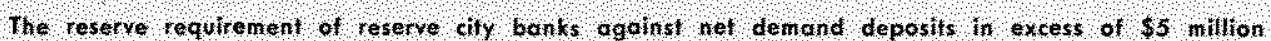

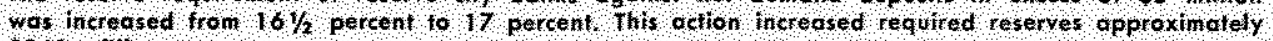
$\$ 360$ million,

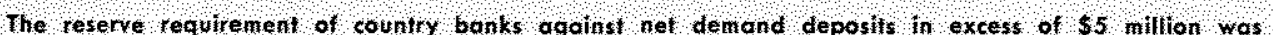

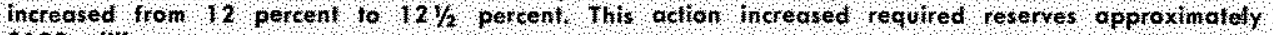
$\$ 190$ millon.

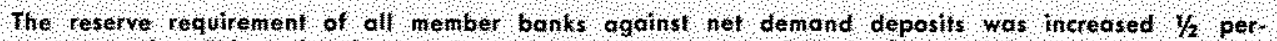
centage point this action increased required resentes approximafely 5660 millon.

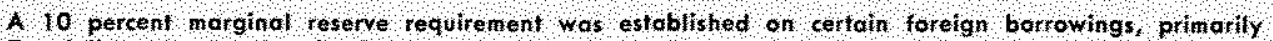

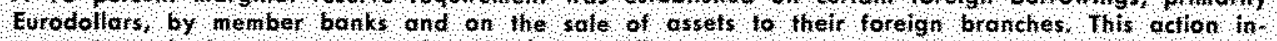
creased required teserves opproximately $\$ 415$ mfllon

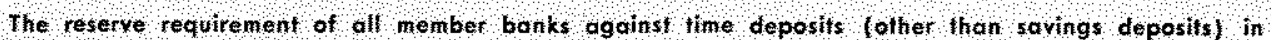
exces of $\$ 5$ anillon wos teduxed from 6 percent fo 5 percent $A t$ fhe same time, a 5 percent re

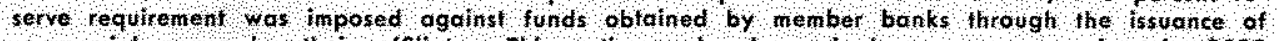

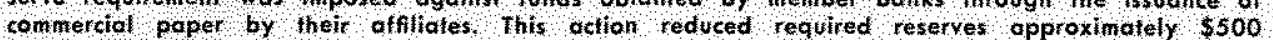
millon (nell.

30 adjustments to legal reserve requirement ratios, as shown in Table IV. Twenty-five of these adjustments took place in the approxinately 10 -year period from mid-1966 to early 1977. Table III shows that these changes frequently resulted in a divergence of 2 to 3 percentage points between the growth rates of an adjusted and an unadjusted measure of monetary base. More important, the direction of change was usually different - one measure indicating an acceleration in the base, the other measure indicating a deceleration or no change in the growth rate.

The data in Table III show a consistent relationship between the difference in the growth rates of the two base series and changes in legal reserve requirements. For example, during a period when reserve requirement ratios were increased (denoted in Table III by a minus sign preceding the amount of 
Effective Dole

lanurly $t, 191$

Novenber 9,1972

Iune 21,197

10112,197

$101 \% 10,197$

oclober 4,1973

Decenter 27,1973

Seplember 10141

becenter 12,1974

rebruony 13,1975

Kay 22,1075

$0 \mathrm{clob}+10,1075$

on $100 \%$ 1976

Decenber 30,1976

\section{Change}

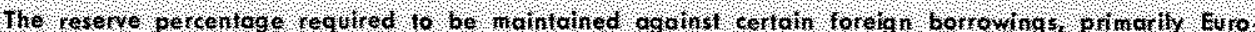
dollars, by nember banks, and the sale of asset, to hert foreigh branches wos raiked hom 10 per. ent 1020 percent this oction had hifle effed on required reserves.

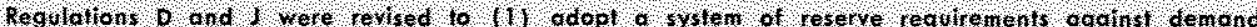
deposils of all nember banks bosed on the amount of surt deposits l ld by o nember bark, and

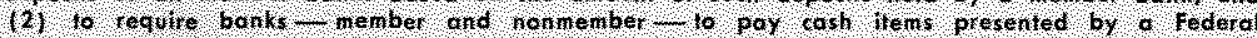
Reserve Bonk en the doy of presentation in funds avoloble to the Reserve Bank on that day These changes redued reavired reserves approximotely $\$ 2.5$ billon, effective Nouember $9,91.0$ billon effective November 16 , and increased required resenves 9300 million, effective November 23 .

The Boord amended It Regulation $D$ o establish a morginal eserve requitentent of 8 percent agains certain time deposits and of subled to the 8 peicent reserve tequirement certoin deposits exempt from

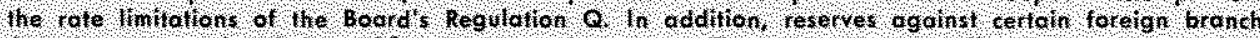
deposits wore leduced trom 10 percent to 8 percent. These ehanges had linte effect on requited reserves.

Geserve qequitenent were imposed ogoinst fhance bill, this odion increased required eserves op. proxinately $\$ 90$ million.

The reserve requirement agolint all net demond deposih, except the firt $\$ 2$ nithon, wos hicreased

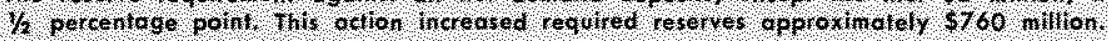

The norginal reserve requirement against certain tithe deposils was hacreased from 8 percent io it

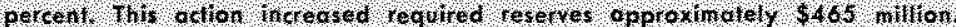

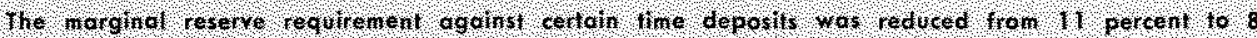
percent This action reduced tequired reserves opproximately $\$ 360$ militon.

The narginal reserve requirerieat against The deposits in denominations greater than $\$ 100.000$ and nore than four nonth noluthy wos eliminoted, this action reduced required reserves approximotely $\$ 310$ milition.

The reserve fequirement agdinst all time deposits with on original naturty of six nonths or longer

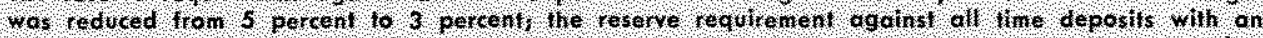
origital noturity of less inon sit menths tas increased trom 5 to 6 percenh ond the reserve require ment agoinst het demand deposits over $\$ 400$ milhon wos ieduced from 18 percent to $17 /$ percent In addition, the 3 percent norginal reserve iequirement on large certifcates of deposti with an

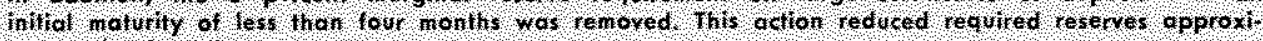
molely $\$ 710$ milition

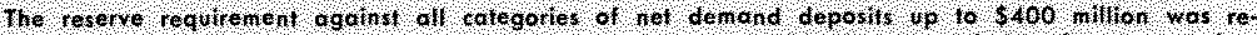

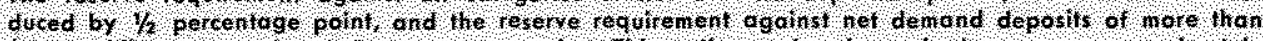
$\$ 400$ million was teduced I percentage point, thil action reduced required reserves approxinately $\$ 1065$ million.

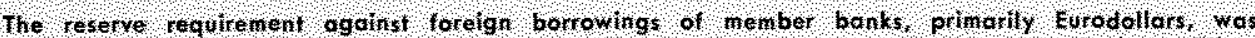

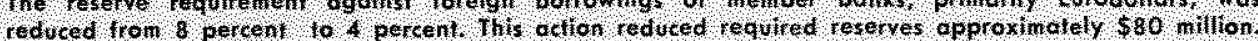

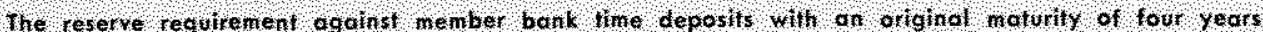

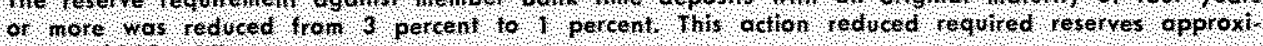
molel $\$ 360$ milon

The tesetre requitement on the deposils maturing in 180 doys 164 years was reduced from 3 per cent to $2 \%$ percent, this collon reduced required reserves by approximately $\$ 500$ mition.

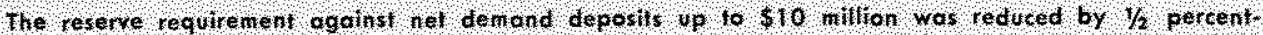
age point, and he reserve requitement against net denand deposits over $\$ 10$ miltion was reduced by 4 percentage point this action leduced required teserves by approximately 8550 milion.

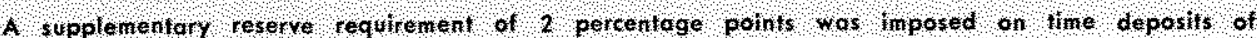

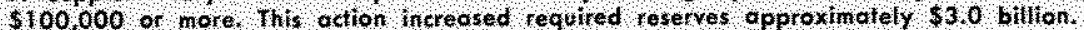

reserves released), an unadjusted monetary base exhibits a faster growth rate than one which has been adjusted. The opposite is clearly the case when reserve requirement ratios are lowered.

The growth rates of the two monetary base series diverge primarily because the Federal Reserve tends to use open market operations to offset the effects of changes in reserve requirement ratios. An increase in reserve requirement ratios, by itself, leads to a sharp rise in the Federal funds rate. Since the Federal Reserve usually follows a policy of preventing sharp fluctuations in the Federal funds rate, it engages in open market operations (increases its rate of purchases of Government securities) to offset the impact of the rise in reserve requirement ratios on interest rates. The effect of open market operations is included in an unadjusted base series, but the opposite effect of 
the increase in reserve requirement ratios is not. Consequently, an unadjusted series shows an acceleration in base growth. When reserve requirement ratios are lowered, the opposite prevails: the unadjusted series shows a reduction in the growth rate of the monetary base.

Therefore, during periods when legal reserve requirement ratios are changed, an unadjusted series gives a misleading indication of both the "intent" and the "effect" of Federal Reserve policy actions. It would be hard to argue that the intent of raising reserve requirement ratios is to "ease" monetary policy, or the intent of lowering them is to "tighten" policy. Furthermore, the only way one can actually judge the effect of such actions on the monetary aggregates is to balance them against the impact of contemporaneous open market operations.

\section{Alternative Adjustments for Reserve Requirement Changes}

This Bank uses the reserve adjustment nagnitude ( $\mathrm{RAM}$ ) to incurporate into the monetary base neasure the effects of ehanges in legal reserve requirement ratios on the nonetary aggregates. In general the computation of RAM involves the following steps?

(1) Deternine the distribution of member bank de. hand ald time deposits subject to reserve re guiremeits. according 10 reserve requirement categonies two weeks eartier.

(2) Gonpare the current reserve requirement ratio with the corresponding 1929 equivalent ratio for each reserve requimement eategory. Muliply the difference bet ween the 1929 cquivalent ratio and the coment ratio by the amount of deposits in that category two weeks ealler. If the current reserve requirement ratio exceeds the 1929 ratio, $\mathrm{MAM}$ is rediced. If the cument ratio is less than the 1029 ratio, $\mathrm{PAM}$ is increased.

(3) Subtract the amoint of required reserves on all deposits subject to special reserve requirements.

(4) Add the amount of waver privileges.

(5) Add the amount of vault cash held by nember banks two weeks earler.

The BOS uses an altemate approach to comput ing $\mathrm{NAM}$ for the adusted monetary base series they began publishing on June 15 , 1979 . The BOS computation involves the following stepst

3The derivation and computation of RAM is described It detal in Burger and Aasche, Tevision of the Monetary Base? 1,22 .

Thor a techitieal description of the nethod used by the BOG to adjust their nonetary base, contact the Banking Section of the Diviston of Research and Statistics at the Board of Covernors in Washington, D, C.
(1) Tor lie week in which teserve reguirements aganst deposits, net demand or time and savMigs, change due to a change in Regulation D. required reserves are ealunated on both the old and the uew resene reguirement basis for the The of deposits aflected.

(2) The ratio of "new' required reserves to "old" required reserves for the partevilar deposit the is calculated and this ratio is applied to actual required reserves for that deposit type for all weeks prior to he change in hegulation D.

(3) As the ratio is applied back through time, it is adiusted for earlier breaks in series dine to changes in Regilation D by nulliplying the cur rent ratio by the ratio calculated at the time of The previous diange in Megulation $D$. (This procedure is camed back, weekly, to laniary 1959. nonthly averages are derived from plorations of the weekly data)

(4) Adustments for breaks in senes due to ehanges. in Regulations $D$ and $W$ affecting other reserv able liabilities (1.e, commercial paper, fmance bills, Eurodollar borrowings, and narginal re. serve requirements agatist large denomination ( 8100,000 or more) $\mathrm{CDs}$ in effect from $\mathrm{mad}$. 1973 to late 1974 ) are made additively. That is, required reserves for earlier periods are raised or lovered by the estimated difference in reserve recuirements that would lave been implied if the regulation had been in eftect in earlier periods:

The major difference between these two alternate procedures is that the $\mathrm{BOC}$ method requires that a new historieally adjusted series which reflects the latest reserve requirement be constructed each time Regulation D or M ehanges, In contrast, the St I louis approach leaves the past data unaltered.

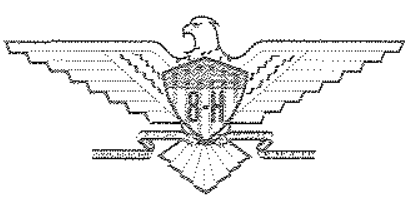

